\title{
Statement of the Uterus Committee of the Gynaecological Oncology Working Group (AGO) on the PORTEC-3 study
}

\section{Stellungnahme der Kommission Uterus der Arbeitsgemeinschaft Gynäkologische Onkologie (AGO) zur PORTEC-3 Studie}

(ㄷ)(1) (옹 $\Theta$

\author{
Authors \\ for the Uterus Committee of the AGO
}

Günther Emons ${ }^{1}$, Clemens Tempfer ${ }^{2}$, Marco Johannes Battista ${ }^{3}$, Alexander Mustea ${ }^{4}$, Dirk Vordermark ${ }^{5}$,

$\Theta$ Deutsche Version unter: https://doi.org/10.1055/a-0658-1918

\section{ABSTRACT}

The data on the adjuvant therapy of endometrial cancer (EC) are inconsistent. Recent studies of this topic such as PORTEC-3, GOG-258 and GOG-249 investigated the value of adjuvant radiotherapy, adjuvant chemotherapy and combined adjuvant chemoradiotherapy followed by chemotherapy in patients with endometrial cancer and an increased risk of recurrence. With this statement, the Uterus Committee of the Gynaecological Oncology Working Group (AGO) wishes therefore to interpret the new data and discuss them against the background of the new S3 guideline "Diagnosis, treatment and follow-up of patients with endometrial cancer”.

\section{ZUSAMMENFASSUNG}

Die Datenlage zur adjuvanten Therapie des Endometriumkarzinoms (EC) ist widersprüchlich. Neue Studien zu diesem Thema wie PORTEC-3, GOG-258 und GOG-249 untersuchten die Wertigkeit der adjuvanten Strahlentherapie, der adjuvanten Chemotherapie und der kombinierten adjuvanten Strahlenchemotherapie gefolgt von einer Chemotherapie bei Patientinnen mit Endometriumkarzinom und einem erhöhten Rezidivrisiko. Die Kommission Uterus der Arbeitsgemeinschaft Gynäkologische Onkologie (AGO) möchte daher mit dieser Stellungnahme die neuen Daten interpretieren und vor dem Hintergrund der neuen S3-Leitlinie „Diagnostik, Therapie und Nachsorge der Patientinnen mit Endometriumkarzinom“ diskutieren.
The data on the adjuvant therapy of endometrial cancer (EC) are inconsistent. In the past year, the results of two important studies, GOG-258 and GOG-249, were presented at the conferences of the American Society of Clinical Oncology (ASCO) and the American Society for Radiation Oncology (ASTRO) [1, 2]. In addi- tion, the results of the PORTEC-3 study were published in full [3]. With this statement, the Uterus Committee wishes therefore to interpret the new data and discuss them against the background of the recently published S3 guideline [4]. 
- Table 1 Recent studies on adjuvant radio-chemotherapy schemes in women with high-risk endometrial cancer.

\begin{tabular}{|c|c|c|c|c|c|c|c|}
\hline Name & Source & n & Inclusion criteria & Therapy & $\begin{array}{l}\text { Freedom from } \\
\text { recurrence }\end{array}$ & Overall survival & Comments \\
\hline $\begin{array}{l}\text { PORTEC- } \\
3\end{array}$ & $\begin{array}{l}\text { De Boer } \\
2018 \\
\text { Lancet } \\
\text { Oncol }\end{array}$ & 686 & $\begin{array}{l}\text { Endometrioid adeno- } \\
\text { carcinoma: FIGO } \\
\text { stage IB and G3 or L1, } \\
\text { FIGO stage II-III } \\
\text { serous or FIGO stage } \\
\text { I-III clear-cell adeno- } \\
\text { carcinoma }\end{array}$ & $\begin{array}{l}48.6 \text { Gy à } 1.8 \text { Gy } \\
\text { versus } \\
48.6 \text { Gy à } 1.8 \text { Gy } \\
\text { and } 2 \times \text { cisplatin } \\
50 \mathrm{mg} / \mathrm{m}^{2} \text { followed } \\
\text { by } 4 \times \text { carboplatin } \\
\text { AUC- } 5+\text { paclitaxel } \\
175 \mathrm{mg} / \mathrm{m}^{2}\end{array}$ & $\begin{array}{l}\text { Failure-free survival } \\
\text { after } 5 \text { years: } \\
68.6 \text { vs. } 75.5 \% \text {; } \\
\text { adjusted HR: } 0.71 \\
\text { ( } 95 \% \text { Cl: } 0.53-0.95 \text { ), } \\
\text { p=0.022 }\end{array}$ & $\begin{array}{l}\text { After } 5 \text { years: } \\
76.7 \text { vs. } 81.8 \% \text {; } \\
\text { adjusted HR: } 0.76 \\
\text { ( } 95 \% \text { Cl: } 0.54-1.06) \text {, } \\
P=0.109 \text {, interim } \\
\text { data }\end{array}$ & $\begin{array}{l}\text { 1. Overall survival } \\
\text { was calculated using } \\
\text { interim data, as } \\
\text { required number of } \\
\text { events will only be } \\
\text { achieved at the end } \\
\text { of } 2018 \text {. } \\
\text { 2. It should be noted } \\
\text { that the authors had } \\
\text { to report an adjusted } \\
\text { HR value. }\end{array}$ \\
\hline GOG-249 & $\begin{array}{l}\text { Randall } \\
\text { \# LBA-1 } \\
\text { ASTRO } \\
2017\end{array}$ & 601 & $\begin{array}{l}\text { FIGO stage I-II, either } \\
\text { high-intermediate } \\
\text { endometrioid } \\
\text { adenocarcinoma or } \\
\text { serous or clear-cell } \\
\text { adenocarcinoma }\end{array}$ & $\begin{array}{l}\text { Percutaneous pelvic } \\
\text { radiation ( } 44.0- \\
54.0 \mathrm{~Gy} \text { ) versus } \\
\text { vaginal brachy- } \\
\text { therapy followed } \\
\text { by } 3 \times \text { carboplatin } \\
\text { AUC- } 6+\text { paclitaxel } \\
175 \mathrm{mg} / \mathrm{m}^{2}\end{array}$ & $\begin{array}{l}\text { Cumulative inci- } \\
\text { dence of recurrence } \\
\text { and metastasis } \\
\text { after } 5 \text { years: } \\
18 \% \text { in both groups }\end{array}$ & $\begin{array}{l}\text { After } 3 \text { years: } \\
91 \text { vs. } 88 \%(p=0.57) \\
\text { interim data }\end{array}$ & $\begin{array}{l}\text { Percutaneous radio- } \\
\text { therapy selected as } \\
\text { the standard even } \\
\text { though data from } \\
\text { PORTEC-2 show that } \\
\text { vaginal brachyther- } \\
\text { apy is equi-effective } \\
\text { and better tolerated. }\end{array}$ \\
\hline GOG-258 & $\begin{array}{l}\text { Matei } \\
\# 5505 \\
\text { ASCO } \\
2017\end{array}$ & 813 & $\begin{array}{l}\text { Endometrioid adeno- } \\
\text { carcinoma FIGO } \\
\text { stage III/IV, residual } \\
\text { tumor }<2 \mathrm{~cm} \text { or } \\
\text { serous or clear-cell } \\
\text { adenocarcinoma } \\
\text { FIGO stage I-II }\end{array}$ & $\begin{array}{l}6 \times \text { carboplatin + } \\
\text { paclitaxel } \\
175 \mathrm{mg} / \mathrm{m}^{2} \\
\text { versus } \\
\text { percutaneous pelvic } \\
\text { radiation with } 2 \times \\
\text { cisplatin } 50 \mathrm{mg} / \mathrm{m}^{2} \\
\text { followed by } 4 \times \\
\text { carboplatin AUC-6 } \\
+ \text { paclitaxel } \\
175 \mathrm{mg} / \mathrm{m}^{2}\end{array}$ & $\begin{array}{l}\text { Recurrence-free } \\
\text { survival after } 5 \text { years: } \\
\text { HR: } 0.9 \text { ( } 95 \% \mathrm{Cl} \text { : } \\
0.74-1.1)\end{array}$ & $\begin{array}{l}\text { After } 5 \text { years: } \\
73 \text { versus } 70 \% \text {, } \\
\text { interim data }\end{array}$ & $\begin{array}{l}\text { Chemotherapy arm } \\
\text { was viewed as the } \\
\text { standard when } \\
\text { designing the study. }\end{array}$ \\
\hline
\end{tabular}

In the Postoperative Radiotherapy in Endometrial Cancer (PORTEC)-1 study published in 2011, doctors in the Netherlands showed that locoregional control is significantly improved by percutaneous pelvic radiation with 46 Gray (Gy) after hysterectomy and bilateral adnexa extirpation in women with unknown lymph node status and an intermediate or high-intermediate risk level (Fédération Internationale des Gynécologues et Obstétriciens [FIGO] endometrioid EC stage IA (in the current version) with $<50 \%$ myometrial infiltration depth, G2 or G3, or FIGO stage IB with > 50\% myometrial infiltration depth, G1 or G2 (vaginal recurrence: 11 vs. $2.5 \%$ ). The rates of pelvic recurrence, distant recurrence and overall survival were not improved by adjuvant radiation [5].

The PORTEC-2 study investigated whether vaginal brachytherapy alone with $3 \times 7$ Gy or 30 Gy can achieve locoregional, especially vaginal, tumour control comparable to that achieved with external-beam pelvic radiation with 46 Gy and 3-D radiation planning in patients with so-called "high-intermediate" risk endometrioid EC (FIGO stage IA in the current version $[<50 \%$ myometrial infiltration] $>60$ years or $\mathrm{G} 3$ or FIGO stage IB [> 50 myometrial infiltration], G1 or G2, or FIGO stage II with endocervical gland involvement, G1 or G2 and < 50\% myometrial infiltration. The vaginal, locoregional and distant recurrence rates did not differ significantly in the two study arms. Likewise, the overall and disease- free survival did not differ significantly, but the side effect profile was better in the brachytherapy group [6].

In the recently published PORTEC-3 study, an international group in 103 centres investigated the benefit of additional chemotherapy during and after percutaneous adjuvant radiotherapy ( $\triangleright$ Table 1) [3]. The study included women with high-risk EC (endometrioid adenocarcinoma, FIGO IB with G3, IA with G3 and lymphatic invasion; endometrioid adenocarcinoma, FIGO II or III; serous or clear-cell EC FIGO I-III). The patients received either teletherapy of 48.6 Gy only or were given cisplatin $\left(50 \mathrm{mg} / \mathrm{m}^{2}\right)$ twice in addition, in the first and fourth weeks of radiation, followed by 4 cycles of carboplatin (AUC5) and paclitaxel $\left(175 \mathrm{mg} / \mathrm{m}^{2}\right) .660$ patients were included in the final analysis. The average followup period was 60.2 months. Just under $60 \%$ of the patients had lymphadenectomy, about $45 \%$ were FIGO stage III, $27 \%$ had endometrioid EC graded G3, and $25 \%$ had serous or clear-cell EC. Failure-free survival (FFS), defined as recurrence or death due to EC or therapy, and overall survival were selected as primary coendpoints for the study.

The 5-year overall survival rate was $81.8 \%$ (95\% confidence interval $[\mathrm{Cl}] 77.5-86.2)$ with chemoradiotherapy vs. $76.7 \%(95 \% \mathrm{Cl}$ 72.1-81.6) with radiotherapy alone (adjusted hazard ratio [HR] 0.76 ; $95 \% \mathrm{Cl} 0.54-1.06$; $p=0.11$ ). The 5 -year FFS was significantly better in the chemoradiotherapy group than in the group that had 
radiotherapy alone (75.5\% [95\% Cl 70.3-79.9] vs. 68.6\% [95\% Cl 63.1-73.4]; adjusted HR 0.71 [95\% Cl 0.53-0.95]; $p=0.02$ ). Without adjustment, the difference in FFS was not significant (HR 0.76 [95\% Cl 0.57-1.02]; $p=0.067$ ). The effects of chemoradiotherapy were seen most clearly in patients with FIGO stage III (increase in the 5-year overall survival from 69.8 to $78.7 \%$; adjusted p value 0.074; improvement in the 5-year FFS 69.3 vs. $58.0 \%$, unadjusted $p$ value 0.031 ). No statistically significant difference was found in the small subgroup of patients with serous carcinoma (5-year FFS of $58 \%$ after chemoradiotherapy and $48 \%$ after radiotherapy (HR 0.63 [95\% Cl 0.36-1.12]; $\mathrm{p}=0.11$ ). Side effects $\geq$ grade 3 occurred in $60 \%$ of patients with chemoradiotherapy compared with only $12 \%$ of patients who had radiotherapy alone ( $p<0.0001)$. Persistent neuropathies ( $\geq$ grade 2 ) were observed after 3 years in $8 \%$ of women after chemoradiotherapy compared with only $1 \%$ after radiotherapy $(p<0.0001)$.

Even if one of the two study endpoints (FFS) was reached after statistical adjustment, the authors conclude from these results that chemoradiotherapy cannot be recommended as the new standard for patients with high-risk EC in FIGO stage I and II. However, this therapy can be discussed with patients in stage III, bearing in mind the considerable toxicity [3]. Moreover, it must be mentioned that the number of events for calculating the overall survival was lower than planned and only $69 \%$ of the required events were observed. Sufficient statistical events to allow a final evaluation of the overall survival data will probably be available only at the end of 2018.

The Uterus Committee of the AGO is of the opinion that adjuvant combined chemoradiotherapy with sequential chemotherapy cannot be regarded currently as the new standard in high-risk EC based on the available results of the PORTEC-3 study.

In certain risk situations (e.g., FIGO stage III and IV after surgery with no or minimal residual tumour), chemotherapy forms the basis of adjuvant therapy [4]. The benefit of additional radiotherapy must be clarified. The benefit of adjuvant chemotherapy combined with vaginal brachytherapy for tumours with a high recurrence risk compared with percutaneous radiotherapy is unclear. Two studies by the Gynecologic Oncology Group (GOG) addressed this topic, though they are not yet available as a full publication ( $\vee$ Table 1). In the GOG-258 study, 813 patients with EC stage III or IVa and postoperative residual tumour $<2 \mathrm{~cm}$ or patients with serous histology in FIGO stage I and II were treated with $6 \times$ carboplatin (AUC5) plus paclitaxel $\left(175 \mathrm{mg} / \mathrm{m}^{2}\right)$ (standard arm) or with chemoradiotherapy according to the protocol of the PORTEC-3 study [1]. The recurrence-free survival and overall survival were similar in both groups (5-year overall survival rate 70 vs. $73 \%$ ). Vaginal recurrences (3 vs. $7 \%$ ) and pelvic and para-aortic recurrences (10 vs. 19\%) were significantly more frequent after 5 years in the group that had chemotherapy alone, but distant metastases were significantly more seldom (27 vs. $21 \%$ ). The final data regarding overall survival are still awaited.

Initial results of the GOG-249 study are currently available as an abstract ( $\triangleright$ Table 1) [2]. This study included 601 patients with EC FIGO stages I and II with high-intermediate risk and endometrioid EC or with serous or clear-cell EC. They received either percutaneous pelvic radiation (44 Gy/25 fractions or $54 \mathrm{~Gy} / 28$ fractions) or vaginal brachytherapy followed by 3 cycles of carboplatin
(AUC6) and paclitaxel $175 \mathrm{mg} / \mathrm{m}^{2}$. The 3-year overall survival (91 vs. $88 \%$ ) and the number of vaginal recurrences and of distant metastases (18 vs. $18 \%$ ) were similarly high in both groups after 5 years. Pelvic and para-aortic recurrences were more frequent in the combined brachytherapy/chemotherapy group (4 vs. 9\%), as was toxicity ( $\geq$ grade 3 events in 62 vs. $11 \%$ ).

For a final interpretation of the three cited studies, the full publications and final survival data are required. With hindsight, it might perhaps have been useful in the GOG-249 study to combine the brachytherapy with the usual 6 instead of 3 cycles of carboplatin/paclitaxel to achieve the full efficacy of the chemotherapy. In the GOG-258 study, locoregional control might possibly have been improved in the chemotherapy arm by additional brachytherapy. There is therefore a danger that the PORTEC-3, GOG-249 and GOG-258 studies will not allow conclusive recommendations on the use of adjuvant radio- and chemotherapy in EC even after publication of the final survival data.

The current S3 guideline "Diagnosis, treatment and follow-up of patients with endometrial cancer" [4] recommends the following procedure:

- "Adjuvant chemotherapy can be given to patients with type II EC and to patients with type I EC G3, pT1b and stage pT2 (all pNO) (Level of Evidence [LoE] 2)."

- "Patients with EC stage pT3 and/or pN1 should receive adjuvant chemotherapy (LoE1)."

- "Patients with EC stage pT4a who were macroscopically tumour-free after surgery or have a maximum residual tumour under $2 \mathrm{~cm}$ should receive chemotherapy (LoE1)."

- "Patients with stage pT1b, pNx, G3 or stage pT2 pNx, endometrioid EC (type I) should receive vaginal brachytherapy. Alternatively, percutaneous radiotherapy can be given (expert consensus, strong consensus 96\%)."

- "Patients who have had systematic lymphadenectomy in stage pT1b, pN0, G3 or stage pT2, endometrioid EC (type I), should receive vaginal brachytherapy. Percutaneous radiotherapy should not be given here (consensus 92\%)."

- "Patients with stage pT1, pNx (any grading) with 'substantial lymphatic invasion' (highest grade in a 3-level grading of lymphatic invasion) can receive percutaneous pelvic radiation instead of vaginal brachytherapy (expert consensus 93\%)."

- "For patients with involved lymph nodes, involvement of the uterine serosa, adnexa, vagina, bladder or rectum (that is, FIGO stages III-IVa) with endometrioid EC (type I), postoperative external pelvic radiation can be given in addition to chemotherapy to improve local control (expert consensus 93\%)."

- "The indication for postoperative vaginal brachytherapy or external pelvic radiation in type II EC (serous or clear-cell histology) should be guided by the recommendations for type I EC (endometrioid adenocarcinoma, G3) of the same stage (expert consensus 95\%)."

These guideline recommendations are valid even after publication of the PORTEC-3 study. A change in the recommendations above based on the results of the PORTEC-3 study published to date is not required. In the opinion of the guideline group, a review will be useful when the final survival data of PORTEC-3, GOG-258 and GOG-249 are published in full. The first update of the S3 guideline 
"Diagnosis, treatment and follow-up of patients with endometrial cancer" is planned for the end of 2019. Until then, the guideline group will continue to check all recommendations for updates.

\section{Conflict of Interest}

The authors declare that they have no conflict of interest.

\section{References}

[1] Matei D, Filiaci V, Randall M et al. A randomized phase III trial of cisplatin and tumor volume directed irradiation followed by carboplatin and paclitaxel vs. carboplatin and paclitaxel for optimally debulked, advanced endometrial carcinoma. J Clin Oncol 2017; 35 (Suppl.): Abstract 5505

[2] The ASCO Post. ASTRO 2017: GOG-249 confirms adjuvant pelvic radiation as standard of care for high-risk, early-stage endometrial cancer. Online: http://www.ascopost.com/News/58092; last access: 23.01.2018
[3] De Boer SM, Powell ME, Mileshkin L et al. Adjuvant chemoradiotherapy versus radiotherapy alone for women with high-risk endometrial cancer (PORTEC-3): final results of an international, open-label, multicenter, randomized, phase 3 trial. Lancet Oncol 2018; 19: 295-309

[4] S3-Leitlinie Diagnostik, Therapie und Nachsorge der Patientinnen mit Endometriumkarzinom. Version 1.0 - April 2018 AWMF-Registernummer: 032/034-OL. Online: https://www.leitlinienprogramm-onkologie. de/leitlinien/endometriumkarzinom/; last access: 30.05 .2018

[5] Nout RA, van de Poll-Franse LV, Lybeert ML et al. Long-term outcome and quality of life of patients with endometrial carcinoma treated with or without pelvic radiotherapy in the post operative radiation therapy in endometrial carcinoma 1 (PORTEC-1) trial. J Clin Oncol 2011; 29: 16921700

[6] Nout RA, Smit VT, Putter $\mathrm{H}$ et al. Vaginal brachytherapy versus pelvic external beam radiotherapy for patients with endometrial cancer of highintermediate risk (PORTEC-2): an open-label, non-inferiority, randomised trial. Lancet 2010; 375: 816-823 